\title{
Mewujudkan Keadilan Sosial dalam Penyelesaian Sengketa Di Pengadilan Administrasi
}

\author{
Indriati Amarini
}

DATA NASKAH:

Masuk: 13 Januari 2017

Diterima: 24 November 2018

Terbit: 31 Desember 2018

KORESPONDEN PENULIS:

Fakultas Hukum Universitas Muhammadiyah Purwokerto

JI. Raya Dukuhwaluh, Dusun III, Dukuhwaluh, Kembaran, Kabupaten Banyumas, Jawa Tengah 53182

\begin{abstract}
Administrative Courts in developing countries carry out more demanding tasks than those in developed countries because they have to be able to keep the balance between protecting public and individual interests. This research raises the issue of how to realize social justice in resolving a dispute in Administrative Courts. This is a doctrinal research using legal, conceptual, and comparative approaches. The research result indicates that Administrative Courts, carry out the oversight function against the acts of government officials, have to realize the justice which becomes the essence of the administrative law's goal, that is social justice. Social justice which is built on the basis of Pancasila, functions to maintain the balance between the individual interest and the society's rights so that the balance and harmony between the government and the people will be created. Furthermore, the Administrative Courts have to be able to realize the social justice, not only normative or procedural justices. Keywords: Social Justice, Disputes, Public and Individual Interest.
\end{abstract}

\section{ABSTRAK}

Pengadilan administrasi di negara-negara yang sedang berkembang mengemban tugas yang lebih berat daripada negara-negara yang sudah mapan sebab harus dapat menjaga keseimbangan antara perlindungan terhadap kepentingan umum dengan kepentingan individu. Penelitian ini mengangkat permasalahan bagaimanakah mewujudkan keadilan sosial dalam penyelesaian sengketa di pengadilan administrasi. Penelitian ini merupakan penelitian doktrinal, menggunakan pendekatan undangundang, pendekatan konseptual dan pendekatan komparatif. Hasil penelitian menunjukkan bahwa pengadilan administrasi melaksanakan fungsi pengawasan terhadap perbuatan pejabat pemerintah, harus mampu mewujudkan keadilan yang menjadi esensi dari tujuan dari hukum administrasi yaitu keadilan sosial. Keadilan sosial dibangun atas dasar falsafah Negara Pancasila berfungsi untuk menjaga keseimbangan antara hak perseorangan dengan hak masyarakat atau kepentingan umum sehingga tercipta keseimbangan, keselarasan, keserasian dan kerukunan antara 
pemerintah dan rakyat. Pengadilan administrasi harus mampu mewujudkan keadilan sosial bukan hanya keadilan normatif apalagi keadilan prosedural semata-mata.

Kata Kunci: Keadilan Sosial, Perselisihan, Kepentingan Publik dan Individu.

\section{PENDAHULUAN}

Pertumbuhan dan perkembangan hukum administrasi negara sangat pesat dikarenakan tugas pemerintah tidak semata-mata di bidang pemerintahan saja melainkan juga harus melaksanakan kesejahteraan sosial dalam rangka mencapai tujuan negara yang dijalankan melalui pembangunan nasional. Pembangunan nasional yang bersifat multikompleks mengakibatkan pemerintah turut campur tangan dalam kehidupan rakyat di semua sektor.

Adanya kewajiban administrasi negara melayani warga negara untuk mewujudkan citizen friendly, negara hukum modern menggunakan hukum administrasi negara sebagai instrumen pengendalian administrasi negara. Penggunaan hukum administrasi, tidak hanya sebagai alat pengatur dan pemaksa, tetapi juga sebagai sarana pembatas kekuasaan negara itu sendiri. Pembatasan kekuasaan negara dirasa perlu, sebab apabila negara diberikan kekuasaan yang terlalu banyak (walaupun berdasar hukum sekalipun), akan menimbulkan kekuasaan yang absolut. Kekuasaan yang absolut, pada gilirannya hanya akan menimbulkan kepemimpinan yang korup (Utama, 2010: 2).

Ada dua hal yang seakan-akan bertentangan terkait kewajiban negara. Pada satu sisi adanya kewajiban negara untuk mengatur dan melayani masyarakat, pada sisi yang lain muncul kekhawatiran adanya kesewenangan dari negara. Oleh karena itu, warga negara membutuhkan jaminan perlindungan hukum yang cukup dari kekuasaan negara yang besar tersebut. Dalam rangka memberikan perlindungan dibutuhkan suatu media atau institusi keadilan yang dapat digunakan sebagai akses bagi masyarakat untuk mendapatkan keadilan. Lembaga pengadilan ini secara simbolik telah menjadi wujud dari pemberlakuan hukum dan keadilan secara nyata. Salah satunya adalah pengadilan administrasi yang memberikan akses keadilan bagi para pencari keadilan di bidang administrasi negara.

Hal ini juga dikemukakan S.F. Marbun bahwa kehadiran lembaga ini menjadi sangat penting untuk memberikan perlindungan hukum terhadap kepentingan individu dan menegakkan serta melindungi hak-hak asasi manusia (Marbun, 2011: 10). Upaya perlindungan hukum yang diberikan oleh pengadilan administrasi menurut Yos Johan Utama harus dipahami dalam satu kerangka berpikir seimbang artinya perlindungan bagi warga masyarakat terhadap tindakan pemerintah harus dilihat selalu dalam kerangka pemikiran kepentingan yang lebih besar. Pemerintah mempunyai tugas besar melayani masyarakat luas maka perlindungan hukum yang sifatnya parsial diberikan manakala hal itu tidak bertentangan dengan kepentingan perlindungan hukum bagi warga masyarakat yang lebih besar. Pengadilan administrasi sebagai lembaga peradilan harus mampu menampung aspirasi dari kedua belah pihak (Utama, 1995: 12).

Bagir Manan menambahkan bahwa fungsi pengadilan administrasi meliputi: Pertama, menegakkan hukum administrasi. Kedua, mengontrol pelaksanaan kekuasaan pemerintah dalam membuat peraturan administrasi atau menerapkan keputusan administrasi. Fungsi kedua merupakan salah satu ciri khas pengadilan administrasi karena tidak selalu dimiliki peradilan umum apalagi peradilan agama dan peradilan militer. Hanya peradilan yang memiliki hak menguji yang akan memiliki fungsi kedua, kalau tidak peradilan tersebut hanya mempunyai fungsi menegakkan hukum "law enforcement, handhaving van het recht" (Manan, 2009: 6). 


\section{RUMUSAN MASALAH}

1. Bagaimana kedudukan pengadilan administrasi sebagai sarana kontrol terhadap pemerintah?

2. Bagaimana keadilan sosial dalam penyelesaian sengketa administrasi?

\section{PEMBAhASAN}

A. Pengadilan administrasi sebagai Sarana Kontrol terhadap Pemerintah

Salah satu fungsi pengadilan administrasi adalah mengontrol pelaksanaan kekuasaan pemerintah dalam membuat peraturan administrasi atau menerapkan keputusan administrasi. Meningkatnya tugas yang harus dilaksanakan oleh pemerintah dalam rangka mewujudkan negara kesejahteraan, menimbulkan konsekuensi terhadap perlunya pengawasan atau kontrol yang lebih efektif dan intensif untuk mengoreksi terjadinya praktik maladmnistrasi yang dilakukan oleh oknum badan atau pejabat administrasi negara. Pengadilan administrasi inilah yang berfungsi melakukan pengawasan atau kontrol terhadap pemerintah.

Inti atau hakikat hukum administrasi negara bersifat ganda yaitu memungkinkan administrasi negara menjalankan fungsinya dan melindungi warga negara terhadap sikap tindak administrasi itu sendiri. Ada dua macam bentuk perlindungan yaitu Pertama, perlindungan hukum yang preventif dimana rakyat diberi kesempatan untuk mengajukan keberatan (inspraak) atau pendapatnya sebelum suatu keputusan pemerintah mendapat bentuk yang definitif, artinya perlindungan hukum ini bertujuan mencegah terjadinya sengketa. Kedua, perlindungan yang represif bertujuan untuk menyelesaikan sengketa melalui peradilan umum, pengadilan administrasi negara dan sebagainya (Husni, 2006: 4). Lembaga pengadilan administrasi merupakan salah satu bentuk perlindungan hukum bagi masyarakat yang bersifat represif selain prosedur keberatan, banding administratif dan ombudsman.

Pengadilan administrasi dibangun atas dasar falsafah Negara Indonesia yaitu Pancasila yang menjaga keseimbangan, keselarasan, keserasian dan kerukunan antara pemerintah dan rakyat. Sebagaimana Philipus M. Hadjon mengemukakan ada empat elemen atau unsur-unsur Negara Hukum Pancasila yaitu: (1) Keserasian hubungan antara pemerintah dan rakyat berdasarkan asas kerukunan, (2) Hubungan fungsional yang proposional antara kekuasaan Negara, (3) Prinsip penyelesaian sengketa secara musyawarah dan peradilan merupakan sarana terakhir; dan (4) Keseimbangan antara hak dan kewajiban (Marbun, 2011: 18).

B. Keadilan Sosial dalam Penyelesaian Sengketa Administrasi

Keadilan merupakan salah satu tujuan terpenting hukum, selain kepastian hukum, kemanfaatan dan ketertiban. Selain tujuan hukum, keadilan dapat juga dilihat sebagai suatu nilai (value). Ada empat nilai yang merupakan fondasi penting bagi suatu kehidupan manusia yang baik yaitu keadilan, kebenaran, hukum dan moral. Namun keadilan merupakan nilai kebajikan yang tertinggi, sebagaimana dikemukakan Plato: "Justices is the supreme virtue which harmonize all other virtues".

Keadilan memiliki ragam makna. Sebagaimana dikemukakan oleh Jimly Asshiddiqie bahwa ide tentang keadilan memang mengandung banyak aspek dan dimensi yaitu keadilan hukum, keadilan politik dan keadilan sosial (Asshiddiqie, 2011: 1). Peragaman makna keadilan menjadikan definisi keadilan beragam pula. Quraish Shihab menjelaskan bahwa ada tiga kata tentang keadilan yaitu qisth, 'adl dan mizan pada berbagai bentuknya yang digunakan $\mathrm{Al}$ Quran dalam konteks perintah kepada manusia untuk berlaku adil. Pertama, QS Al-A'raf ayat 29: "Katakanlah, Tuhanku memerintahkan menjalankan al-qisth (keadilan)". Kedua, QS Al Nahl ayat 90: "Sesungguhnya Allah memerintahkan berlaku adil dan berbuat ihsan (kebajikan)". Ketiga, QS AlRahman ayat 7-8: "Dan langit ditinggikan-Nya dan Dia meletakkan neraca (keadilan) agar kamu tidak melampaui batas tentang neraca itu" (Shihab, 2013: 151). 
Selanjutnya paling tidak ada empat makna keadilan yang dikemukakan oleh para pakar agama yaitu pertama, adil dalam arti sama, namun persamaan yang dimaksud adalah persamaan dalam hak. Dalam surat An-Nisa ayat 58: "Apabila kamu memutuskan perkara diantara manusia, maka hendaklah engkau memutuskannya dengan adil". Kata adil dalam ayat ini bila diartikan sama hanya mencakup sikap dan perlakuan hakim pada saat proses pengambilan keputusan. Kedua, adil dalam arti seimbang. Keseimbangan ditemukan pada suatu kelompok yang didalamnya terdapat beragam bagian yang menuju satu tujuan tertentu, selama syarat dan kadar tertentu terpenuhi oleh setiap bagian. Dengan terhimpunnya syarat ini, kelompok itu dapat bertahan dan berjalan memenuhi tujuan kehadirannya. Dalam QS Al-Infithar ayat 6-7: "Wahai manusia, apakah yang memperdayakan kamu (berbuat durhaka) terhadap Tuhanmu Yang Maha Pemurah? Yang menciptakan kamu lalu menyempurnakan kejadianmu dan mengadilkan kamu (menjadikan susunan tubuhmu seimbang)". Ketiga, adil adalah perhatian terhadap hak-hak individu dan memberikan hak-hak itu kepada setiap pemiliknya. Pengertian inilah yang didefinisikan dengan menempatkan sesuatu pada tempatnya atau memberi pihak lain haknya melalui jalan yang terdekat. Lawannya adalah kezaliman dalam arti pelanggaran terhadap hak-hak pihak lain. Pengertian keadilan seperti ini melahirkan keadilan sosial. Keempat, adil yang dinisbatkan kepada Ilahi. Adil disini berarti memelihara kewajaran atas berlanjutnya eksistensi, tidak mencegah kelanjutan eksistensi dan perolehan rahmat sewaktu terdapat banyak kemungkinan untuk itu (Shihab, 2013: 152).

Dalam pandangan budaya atau etika jawa, nilai keadilan juga menempati sendi penting dalam interaksi sosial. Sebagaimana R. Ng. Ranggawarsita menempatkan nilai-nilai keadilan tersebut dalam posisi yang cukup penting. Hal ini terlihat dalam ungkapan "aja mban cindhe mban siladan". Norma sosial tersebut sebagai tuntutan sosial terutama bagi seseorang yang menempati posisi sebagai pemimpin. Anjuran berlaku adil itu dibebankan pada "semua orang" karena pada dasarnya setiap orang adalah pemimpin bagi diri sendiri, keluarga, maupun masyarakat atau pemerintahan (Kholidah, 2014: 39).

Makna keadilan mengandung nilai moral universal yang merupakan hak dan kebutuhan dasar manusia di seluruh dunia. Nilai moral keadilan tersebut menjadi cita-cita setiap bangsa yang didalamnya terdapat kepentingan berbagai golongan. Oleh karena itu, keadilan menjadi kesepakatan di antara berbagai unsur masyarakat yang menginginkan kehidupan bernegara yang adil dan makmur. Begitupun dengan bangsa Indonesia telah tercantum dalam sila ke-lima Pancasila yaitu keadilan sosial bagi seluruh rakyat Indonesia. Hal ini telah menjadi ikrar seluruh bangsa Indonesia dan merupakan cita-cita seluruh bangsa Indonesia.

Persoalan keadilan sosial juga tidak luput dari tinjauan ilmu kenegaraan (staatsleer, political science) dan teori hukum (negara hukum dalam arti material) yang dikenal dengan sebutan negara kesejahteraan, welfare state atau welfaarsstaat, verzorgingsstaat. Sebagaimana menurut paham negara kesejahteraan, negara tidak sekedar sebagai penjaga keamanan dan ketertiban atau sekedar menjamin kelangsungan hidup seorang atau masyarakat. Negara memikul tanggung jawab dan bekewajiban mewujudkan kesejahteraan dan keadilan sosial bagi seluruh rakyat. Oleh karena itu, negara turut serta dalam pergaulan masyarakat dan bukan sesuatu yang berada di luar atau di atas masyarakat.

Ada beberapa makna keadilan sosial. Dalam kamus Black's Law Dictionary social justice : justice that conform to moral principle, such as that all people are equal. Sedangkan dalam Kamus Besar Bahasa Indonesia, keadilan sosial didefinisikan sebagai kerjasama untuk mewujudkan masyarakat memiliki kesempatan yang sama dan nyata untuk tumbuh berkembang sesuai kemampuan masing-masing.

Selanjutnya Quraish Shihab mengemukakan tentang keadilan sosial yaitu Al Quran menetapkan 
bahwa salah satu sendi kehidupan bermasyarakat adalah keadilan (tidak lebih dan tidak kurang). Berbuat baik melebihi keadilan seperti memaafkan yang bersalah atau memberi bantuan kepada yang malas akan menggoyahkan sendi-sendi kehidupan bermasyarakat. Memang Al Quran memerintahkan perbuatan adil dan kebajikan seperti bunyi firmanNya: "Sesungguhnya Allah menyuruh (kamu) berlaku adil dan berbuat kebajikan” (QS Al Nahl ayat 90), karena ihsan (kebajikan) dinilai sebagai sesuatu yang melebihi keadilan. Namun dalam kehidupan bermasyarakat, keadilan lebih utama daripada kedermawanan atau ihsan. Keadilan sosial bukan mempersamakan semua anggota masyarakat, melainkan mempersamakan mereka dalam kesempatan mengukir prestasi. Selanjutnya hubungan keadilan sosial dan kesejahteraan adalah apabila diantara mereka ada yang tidak dapat meraih prestasi atau memenuhi kebutuhan pokoknya, masyarakat yang berkeadilan sosial terpanggil untuk membantu mereka agar mereka pun dapat menikmati kesejahteraan sosial. Oleh karena itu keadilan akan mengantarkan kepada kesejahteraan (Shihab, 2013: 165).

Istilah keadilan sosial juga termuat dalam Piagam Jakarta 22 Juni 1945 dan Pembukaan Undang-Undang Dasar 1945. Soekarno dalam Sidang BPUPKI tanggal 1 Juni 1945 menggunakan istilah keadilan sosial dan kesejahteraan sosial yang merupakan terjemahan dari "sociale rechtvaardigheid". Pada umumnya paham keadilan sosial adalah paham dalam makna ekonomi yaitu kesejahteraan ekonomi. Sebagaimana dikemukakan Soekarno bahwa "...prinsip kesejahteraan, prinsip tidak akan ada kemiskinan dalam Indonesia medeka” (Manan, 2014: 11).

Keadilan sebagai suatu tujuan sebagaimana dikemukakan Bagir Manan bukan monopoli satu aliran pikiran tertentu. Bahkan Adam Smith yang dipandang sebagai sumber pemikiran ekonomi liberal dan ekonomi pasar juga bermaksud mewujudkan kesejahteraan sosial dan keadilan sosial dengan menyebutnya no society can surely flourishing and happy, of which by far the greater part of the number are poor and miserable (tidak ada suatu masyarakat yang akan benarbenar maju dan bahagia, apabila sebagian besar rakyatnya miskin dan papa). Selanjutnya ungkapan Jeremy Bentham tentang the greatest happiness for the greatest number. Henri de Saint Simon seorang ahli pikir Perancis terkenal yang mengungkapan : from each according to his ability, to each according to his need (dari tiap orang sesuai kemampuannya, kepada tiap orang sesuai kebutuhannya) (Manan, 2014: 12).

Secara ideologis, para Founding Father dan The Framers of the Constitution ketika membahas konsepkonsep dasar Undang-Undang Dasar 1945 sepakat menolak segala bentuk sistem kapitalisme, liberalisme dan individualism. Namun Bagir Manan menyampaikan bukan berarti Undang-Undang Dasar 1945 menghendaki jalan Marxisme untuk mewujudkan keadilan sosial (dengan jargon revolusi, kediktatoran proletariat, penindasan kepentingan perorangan, penguasaan seluruh alat produksi oleh negara). Hal ini didasari pendapat Mohammad Hatta bahwa ada tiga paham yang mendasari demokrasi sosial untuk menuju keadilan sosial yaitu Pertama, paham sosialisme Barat, yang menarik perhatian karena dasar kemanusiaan, yang dibelanya dan menjadi tujuan. Kedua, ajaran Islam yang menuntut kebenaran dan keadilan ilahi dalam masyarakat serta persaudaraan, antara mereka sebagai makhluk Tuhan, sesuai dengan sifat Allah yang Pengasih dan Penyayang. Ketiga, pengetahuan bahwa masyarakat Indonesia berdasarkan kolektivisme.

Menurut Soediman Kartohadiprodjo makna keadilan sosial bagi bangsa Indonesia sebagai berikut: Pertama, keadilan sosial dalam pandangan Soediman adalah sebuah gagasan yang sangat abstrak. Walaupun ia memulai analisisnya dengan menyatakan bahwa tiap-tiap individu pasti memiliki empat unsur atau alat perlengkapan hidupnya yakni raga, rasa, rasio dan (hidup dengan) rukun, Soediman tidak ingin terjerumus pada paham individualistis. Ia menekankan pentingnya keempat hal tersebut untuk 
dijaga dengan sebaik-baiknya agar ada ketenteraman, keseimbangan dan harmoni. Kemampuan menjaga keempat hal ini dimaknai dengan kebahagiaan. Jadi keadilan sosial adalah kesejahteraan sosial. Kesejahteraan sosial adalah kebahagiaan. Kedua, apabila kata kunci dari keadilan sosial adalah kesejahteraan dan kebahagiaan maka tatkala kata-kata kunci tersebut diterapkan di dalam konteks negara hukum, gagasan ini seharusnya dapat juga dibaca sebagai gagasan negara (hukum) kesejahteraan. Ketiga, revolusi hukum dimaknai oleh Soediman sebagai perubahan kesadaran hukum untuk hidup sebagai bangsa merdeka. Keempat, pemikiran Soediman tentang keadilan sosial dan revolusi hukum (sebagai bagian dari revolusi total Soekarno) memberi penguatan pada gagasan-gagasan besar dari Soekarno, diperlukan penyesuaian-penyesuaian pemikiran sesuai konteks pada saat ini (Sidharta, 2015: 37).

Selanjutnya makna keadilan sebagaimana dikemukakan oleh John Rawls bahwa keadilan adalah kebajikan utama dalam institusi sosial. Masyarakat yang tertata dengan baik adalah jika tidak hanya dirancang untuk meningkatkan kesejahteraan anggotanya, namun secara efektif diatur oleh konsepsi publik mengenai keadilan yaitu Pertama, setiap orang menerima dan mengetahui bahwa orang lain menganut prinsip keadilan yang sama. Kedua, institusi-insitusi sosial dasar pada umumnya sejalan dengan prinsip-prinsip tersebut. Dalam hal ini institusi dianggap adil ketika tidak ada pembedaan sewenang-wenang antar orang dalam memberikan hak dan kewajiban dan ketika aturan menentukan keseimbangan yang pas antara klaim-klaim yang saling berseberangan demi kemanfaatan kehidupan sosial. Ketiga, adanya prinsip keseimbangan dan kelayakan pada pembagian keuntungan dalam kehidupan sosial. Keadilan sosial disini melibatkan persoalan tentang efisiensi, koordinasi dan stabilitas. Dalam hal ini John Rawls banyak berbicara tentang keadian di bidang ekonomi (Fadhilah, 2012: 27).
Berdasarkan pokok pikiran pertama sebagaimana diuraikan John Rawls di atas, dalam konteks ke-Indonesiaan, teori keadilan harus sesuai dengan kebenaran menurut sistem pemikiran bangsa Indonesia. Begitu pula dengan keadilan hukum, tentunya harus sesuai dengan hukum yang berlaku di Indonesia. Sistem pemikiran bangsa Indonesia dan keadilan hukum di Indonesia seharusnya juga sejalan dengan ideologi bangsa dan landasan hukum negara Indonesia yaitu Pancasila dan Undang-Undang Dasar 1945.

Makna keadilan sosial bagi seluruh rakyat Indonesia sesuai dengan Pembukaan UndangUndang Dasar 1945 termuat dalam kata-kata terakhir alinea yang keempat sebagai penjelmaan naskah Proklamasi yang berisi tujuan didirikannya Negara Republik Indonesia. Kadilan sosial dalam hal ini meliputi seluruh bidang kehidupan masyarakat yaitu bidang politik, sosial, ekonomi, pendidikan, pertahanan dan keamanan. Pokok pikiran kedua dalam peran keadilan menekankan bahwa lembaga/institusi-institusi dasar yang ada juga harus berjalan sesuai dengan prinsip keadilan dengan memberikan perlakuan yang sama kepada setiap anggota masyarakat, tanpa ada diskriminasi dalam pelayanan publik, semua anggota masyarakat memiliki hak dan kewajian yang sama. Oleh karena itu setiap kebijakan publik harus mempertimbangkan nilai-nilai keadilan sosial sehingga tidak menimbulkan kecemburuan berbagai kelompok yang merasa dirugikan. Hal tersebut menjadi dasar kebijakan publik yang mengarah pada upaya menjaga stabilitas nasional dengan terciptanya pemerintahan yang adil. Pokok pikiran yang ketiga dalam peran keadilan tersebut diatas menyangkut bidang kehidupan sosial ekonomi yaitu adanya prinsip keseimbangan dan kelayakan dalam pembagian keuntungan. Dalam hal ini makna keadilan sebagai faimess bukan merupakan prinsip yang berdiri sendiri melainkan melibatkan persoalan tentang efisiensi, koordinasi dan stabilitas dalam konteks keIndonesiaan, berimplikasi tidak hanya menyangkut 
bidang sosial ekonomi, melainkan menyangkut seluruh bidang kehidupan baik sosial, politik, pertahanan dan keamanan Indonesia yang membutuhkan keahlian dari sumber daya manusia Indonesia sesuai dengan bidangnya masing-masing (Fadhilah, 2012: 29).

Sebagaimana diuraikan diatas maka ada persamaan prinsip antara teori keadilan John Rawls antara lain sama-sama menghargai hak-hak dasar individu dalam posisi asali tanpa diskriminasi untuk mewujudkan keadilan sosial melalui prinsip demokrasi atau hasil kesepakatan bersama. Berbagai perbedaan kepentingan antar golongan dalam masyarakat maka demokrasi yang menghasilkan kesepakatan tentang keadilan sosial harus memperhatikan nasib golongan yang paling tidak beruntung dalam masyarakat, sehingga tidak menghalalkan segala cara dengan mengorbankan kepentingan/hak individu demi kepentingan sosial. Meskipun bagi bangsa Indonesia kepentingan sosial berada di atas kepentingan individu tetapi tidak berarti menghilangkan hak individu sebagaimana dalam sistem sosialis komunis dan paham utilitarianisme yang berlandaskan teori etika teleologis.

Undang-Undang Dasar Republik Indonesia tahun 1945 menghendaki Indonesia sebagai negara sosial atau sozialstaat. Adapun inti sozialstaat adalah keadilan sosial atau social justice yang berisi kesejahteraan umum atau kesejahteraan social atau social welfare (Bagir Manan, 2014: 35). Keadilan sosial adalah sila kelima dalam Pancasila. Sila kelima ini tidak lain merupakan ujung harapan dari semua sila lainnya. Sila pertama sampai dengan sila keempat saling berkaitan satu sama lain. Kesemuanya harus menghasilkan keadilan sosial bagi seluruh rakyat. Oleh karena itu perumusan kelima sila itu pada Alinea IV Pembukaan Undang-Undang Dasar 1945 diakhiri kalimat "serta dengan mewujudkan keadilan sosial bagi seluruh rakyat Indonesia” (Asshiddiqie, 2011: 1)
Penerapan konsep abstrak ke dalam rumusanrumusan hukum dan selanjutnya bagaimana penerapannya di dalam masyarakat sering menimbulkan persoalan khususnya persoalan yang menyangkut keadilan karena hukum merupakan makna simbolik yang memerlukan interpretasi lebih lanjut. Oleh karena itu persoalan keadilan pun yang dirumuskan orang tergantung dari sisi mana melihatnya. Sebagaimana dicontohkan keadilan di bidang kekeluargaan tidak akan sama dengan masalah keadilan di bidang pidana, bidang ketatanegaraan dan seterusnya, sehingga wajah keadilan bersifat dimensional (Warassih, 2001: 19).

Pengadilan administrasi dalam sistem hukum berlandaskan Pancasila sebagai dasar moral bagi tertib hukum Indonesia, sudah seharusnya mampu mewujudkan keadilan. Keadilan yang hendak diwujudkan dalam penyelesaian sengketa administrasi adalah keadilan sosial yaitu adanya keseimbangan antara kepentingan pribadi dan kepentingan bersama. Hukum mengemban fungsi ekspresif dan fungsi instrumental. Hukum dikatakan mengemban fungsi ekspresif yakni mengungkapkan pandangan hidup, nilai-nilai budaya dan keadilan. Selain itu, hukum juga mengemban fungsi instrumental yakni sarana untuk menciptakan dan memelihara ketertiban, stabilitas dan prediktabilitas, sarana untuk melestarikan nilai-nilai budaya dan mewujudkan keadilan, sarana pendidikan dan pengabdian masyarakat dan sarana pembaharuan masyarakat (Tjandra, 2011: 80).

Dalam asas keserasian, keseimbangan serta keselarasan tersebut mengandung pula adanya ide keseimbangan antara kepentingan individual dan kepentingan umum yang menyangkut banyak orang. Oleh karena itu bukanlah semata-mata perlindungan individu yang ditonjolkan sekalipun mengalahkan kepentingan umum, namun sebaliknya juga jangan sampai alasan kepentingan umum menjadi dalih untuk merugikan atau menekan hak individu dalam masyarakat. 
Hal inilah yang membedakan pengadilan administrasi kita dengan pengadilan administrasi di negara-negara maju yang menganut paham individualisme-liberalisme serta berlatar belakang falsafah dan budaya serta sosial politik yang berbeda seperti di Perancis, Belanda dan Jerman. Namun demikian, paham individualistik dalam praktik negara-negara tersebut, tidak berlaku secara mutlak. Hal ini terlihat dalam perkembangan yurisprudensi dari conseil d'Etat, ada kecenderungan untuk melihat kepentingan umum atau kepentingan orang banyak yang harus dilindungi.

Hakim dalam semua tingkatan menduduki posisi sentral dalam proses peradilan. Dalam posisi yang sentral itulah diharapkan dapat menegakkan hukum dan keadilan. Persoalan yang perlu diselesaikan oleh hakim adalah bagaimana keadilan yang bersifat abstrak yang berisi nilai-nilai tertentu dapat dijadikan pegangan dalam penerapannya. Pekerjaan untuk mewujudkan ide dan konsep keadilan ke dalam bentuk-bentuk konkrit sehingga diterima oleh masyarakat, merupakan pekerjaan hakim. Hakim diharapkan memiliki kemampuan menterjemahkan nilai-nilai keadilan dalam persoalanpersoalan yang dihadapkan kepadanya melalui putusan-putusannya.

Kehadiran pengadilan administrasi yang menjalankan fungsi pengawasan terhadap perbuatan tata usaha negara dari pejabat pemerintah harus mampu mewujudkan keadilan yang menjadi esensi dari tujuan dari hukum. Putusan pengadilan administrasi harus mampu mewujudkan keadilan sosial (social justice) bukan hanya keadilan normatif (normative justice) apalagi keadilan prosedural sematamata (Tjandra, 2011: 77).

\section{SIMPULAN DAN SARAN}

\section{A. Simpulan}

Pengadilan administrasi di negara-negara yang sedang berkembang (developing countries) mengemban tugas yang lebih berat daripada negara-negara yang sudah mapan (settled) sebab harus dapat menjaga dalam keseimbangan yang harmonis dan selaras antara perlindungan terhadap kepentingan umum dan pelayanan umum (public service) dengan pelindungan terhadap kepentingan individu. Dengan kata lain kepentingan pembangungan yang menyangkut kehidupan orang banyak dan kepentingan umum tidak boleh dihambat oleh kepentingan individu. Sebaliknya hak-hak individu pun tidak boleh dilanggar secara sewenang-wenang dengan dalih untuk kepentingan umum dan pembangunan. Oleh karena itu, ada dua istilah yang seolah berhadap-hadapan yaitu antara kepentingan individu (individual interest) dengan kepentingan umum (public interest) namun tidak selamanya kedua kemungkinan itu tidak sejalan. Keberadaan negara dan penyelenggara negara bukanlah untuk meniadakan salah satunya tetapi lebih untuk mencari keseimbangan antara kedua kutub tersebut tanpa harus meniadakan yang satu atau yang lainnya. Dalam sistem kenegaraan Indonesia maka pendulum dari kedua kutub tersebut berada pada titik yang lebih mendekati kutub kepentingan umum. Hal ini bisa terlihat dalam Undang-Undang Dasar 1945 bahwa kolektivitas, kebersamaan, gotong royong lebih diutamakan dari kepentingan-kepentingan yang lebih sempit. Demikian pula secara tradisional, nilai-nilai budaya yang ada dalam masyarakat cenderung lebih menekankan kebersamaan daripada individualisme.

\section{B. Saran}

1. Putusan pengadilan administrasi harus mampu mewujudkan keadilan sosial (social justice) yaitu keseimbangan antara kepentingan individu (individual interest) dengan kepentingan umum (public interest).

2. Hakim pengadilan administrasi dalam menjalankan tugas mewujudkan keadilan sosial tidak cukup hanya memakai landasan yuridis semata tetapi juga landasan filosofis dan sosiologis. 


\section{DAFTAR PUSTAKA}

\section{Buku}

Garner, Bryan A., 1999, Black's Law Dictionary. Seventh Edition. St. Paul, West Group

Marbun, S. F., 2011, Pengadilan Administrasi Negara dan Upaya Administratif Di Indonesia, Yogyakarta, FH UII Press.

Kamus Bahasa Indonesia, 2008, Jakarta, Pusat Bahasa Departemen Pendidikan Nasional.

Shihab, M. Quraish, 2013, Wawasan Al-Quran Tafsir Tematik Atas Pelbagai Persoalan Umat, Bandung, Mizan.

\section{Jurnal}

Fadhilah, 2012, "Refleksi Terhadap Makna Keadilan Sebagai Fairness Menurut John Rawls Dalam Perspektif Ke-Indonesiaan”, Jurnal Kyberman, Vol. 3 No. 1 Maret.

Husni, M., 2006, "Moral Dan Keadilan sebagai Landasan Penegakan Hukum yang Responsif", Jurnal Equality, Vol. 11 No. 1 Februari.

Shidarta, 2015, "Membaca ulang Pemaknaan

Keadilan Sosial Dalam Gagasan Revolusi

Hukum Soediman Kartohadiprodjo", Jurnal Veritas et justitia, Volume 1.

Tjandra, Willy Riawan, 2011, "Dinamika Keadilan

Dan Kepastian Hukum Dalam Peradilan Tata

Usaha Negara", Jurnal Mimbar Hukum Edisi Khusus, November.

\section{Makalah}

Manan, Bagir, "Masa Depan Peradilan Tata Usaha Negara", Majalah Varia Peradilan No. 281 April 2009.

Manan, Bagir, "Semangat Penyelenggara Negara dan Rechtsidee UUD 1945”, makalah materi perkuliahan pada Program Doktor Ilmu Hukum UNS, tanggal 16 Mei 2014.

Manan, Bagir, "Peranan Hukum Dalam mewuudkan Cita-cita Keadilan Sosial Menurut UUD 1945”, Majalah Varia Peradilan No. 340 Maret 2014.
Warassih, Esmi, "Pemberdayaan Masyarakat Dalam Mewujudan Tujuan Hukum (Proses Penegakan Hukum dan Persoalan Keadilan)", Makalah Pidato Pengukuhan Guru Besar Madya, Semarang 14 April 2001

Utama, Yos Yohan, 2010, Membangun Peradilan Tata Usaha Negara Yang Berwibawa. Makalah Pidato Pengukuhan Guru Besar Universitas Diponegoro.

\section{Website}

Asshiddiqie, Jimly, "Pesan Konstitusional Keadilan Sosial”, http://www.jimly.com. diakses Rabu, 4 Januari 2017

Kholidah, Nikmatul, 2014, "Konsep Keadilan dalam Serat Kalatidha karya Raden Ngabehi Ranggawarsita”, http//www.eprints.walisongo.ac.id. diakses Rabu, 11 Januari 2017

Utama, Yos Yohan, "Upaya Perlindungan Hukum Bagi Masyarakat Yang Dilakukan Oleh Peradilan Tata Usaha Negara”, makalah dalam forum diskusi tanggal 4 Juli 1995, hlm. 12 http//eprints.undip.ac.id diakses Senin, 9 Januari 2017

\section{Peraturan Perundang-Undangan}

Undang-undang Nomor 5 Tahun 1986 tentang Peradilan Tata Usaha Negara .

Undang-undang Nomor 9 Tahun 2004 tentang Perubahan atas Undang-undang Nomor 5 Tahun 1986.

Undang-undang Nomor 51 Tahun 2009 tentang Perubahan Kedua atas Undang-undang Nomor 5 Tahun 1986.

Undang-undang Nomor 30 Tahun 2014 tentang Administrasi Pemerintahan. 